\title{
Narrative Ethics in Robert Westall's The Machine Gunners
}

\author{
Vera Nelleke Veldhuizen ${ }^{1,2}$ (D)
}

Published online: 5 February 2020

(c) The Author(s) 2020

\begin{abstract}
One of the particularly challenging aspects of children's literature lies in its ethics. The intended audience of children's literature is often perceived to be morally malleable, and particularly vulnerable to narrative strategies. This why it is of high importance to consider the moral contents which children's narratives attempt to communicate to the implied child reader and what narrative strategies are used to communicate them. In this paper I employ a classic narratological approach to analyse the many different ways through which children's literature both constructs and communicates ethics to its young readership, both on the separate story/discourse levels and in an underlying, philosophical sense. Robert Westall's The Machine Gunners serves as the example text analysis for this purpose, as the heightened stakes and emotions of war stories such as this one also increase the importance placed on moral reasoning, judgements, and consequences. In my analysis I show how certain ethical messages are communicated through different narrative strategies, and how these can either strengthen or contradict one another. This contradiction is potentially particularly confusing for young readers, and the resulting dissociation may undermine the moral framework of the work at large. This is why, at the end of the article, I call for a holistic narratological framework in the analysis of ethics.
\end{abstract}

\section{Keywords Robert Westall · The Machine Gunners · Narrative ethics · Cognitive narratology $\cdot$ Children's war literature}

\footnotetext{
Vera Nelleke Veldhuizen is a final year children's literature PhD Candidate at the Education Faculty at the University of Cambridge. Her research project is focused on cognitive narratology, analysing specifically how the narrative structures of children's war literature construct and communicate empathy, ethics, and justice. She is supervised by Professor Maria Nikolajeva. Her most recent publication is "Empathy Across Time in Speculative Children's Shoah Fiction" in The English Association: Issues in English.
}

Vera Nelleke Veldhuizen

vera.n.veldhuizen@gmail.com

1 University of Cambridge, Cambridge, UK

2 University of Groningen, Groningen, Netherlands 
Literature, like all human action and creation, is inextricably ethical. There is an ethics of creation (why this text was written, what was its purpose, how was it written), an ethics in the creation, and an ethics of reading. These issues are highly emphasised in children's literature because of the power inequity inherent in its nature. All literature is ideological, yet the debate surrounding the ethics of children's literature is seen as a separate, more intense issue than that of the normative "adult" literature. This is because of the special status the child holds in Western culture as a person who is not in a state of being, but a state of becoming (Hollindale, 2011, p. 12). An unfinished project of socialisation and education, the child will, if they get to live a full life, inevitably grow up into adulthood and join adult society.

Children's literature plays a key role in this socialisation, and particularly in the case of ethical socialisation and education raises the issue of responsibility. As Clémentine Beauvais states, "ethical instruction has always formed part of children's literature" (2015, p. 108), and literature plays a strong role "as a facilitator of ethical life, as a companion in ethical choices, and more generally as a participant in the ethical climate of a given society" (p. 109). The children's literature project implies a certain perceived moral malleability of the child, or at least the adult's desire to impart moral lessons to the child reader to shape the potential future adult. Conceptualising the child reader as such puts the existence of children's literature to the moral question: if the intended audience of a text is indeed morally malleable, what are the ethical implications of writing and propagating such texts and the messages therein? Additionally, what are the moral contents the texts attempt to communicate to the implied child reader and what narrative strategies are used to communicate them?

Every narrative element plays a role in the construction of the narrative's ethics and the way it is communicated to the implied reader. In analysing these narrative ethics, it is important to follow the advice put forward by Peter Hollindale in his analysis of ideology in children's literature (2011, pp. 28-51), and by Claudia Mills in her discussion of ethics in children's literature on the multifaceted nature of moral communication:

Sometimes, the expression of values in a work of literature is deliberate and overt on the part of its author; at other times, to determine the values that a work expresses requires considerable analysis on the part of a community of readers, with lively debate over exactly what these values should be taken to be. And at still other times, the deliberate and overt values that an author tries to convey in a work may be contradicted or undermined by competing values that emerge from the work without the author's conscious intent. Moreover, that a book contains a main character, or even a narrator, who expresses certain values is not enough for us to say that these are the values expressed by the work as a whole (Mills, 2014, pp. 5-6).

Mills is correct in pointing out that the morals put forward by a narrative are not always clear-cut, and may be undermined by certain other aspects of the text. One text which suffers from this is, for instance, Joe Haldeman's The Forever War (1974), where the narrator and protagonist claims sexual liberalism but 
homosexuality is framed as degenerate. In the case of a readership which is cognitively still developing, and may not yet have the mind-modelling skills necessary to correctly ascribe character's intentions, emotions, and therefore moral frameworks (Nikolajeva, 2018, p. 83), these clashes of morality are especially interesting for analysis. Children's literature aims to instruct the implied child reader through its narrative structures; what and how it communicates are important particularly because of its readership.

Narrative ethics is not a dry element of a narrative; it is an inherent aspect of literature closely linked to engagement. As Maria Nikolajeva states, the notion that the emotions and ethics are separate has been debunked and their close relation made explicit (2018, p. 82). Literary scholars such as Suzanne Keen (2007), Blakey Vermeule (2010), Patrick Colm Hogan (2011), and Maria Nikolajeva (2014, 2018), as well as, before them, literary philosophers like Wayne C. Booth (1992) and Martha Nussbaum $(1990,2001)$ all theorise about the importance of emotions in ethical decision-making and the role this plays in literature and readership. Interesting specifically for cognitive (ethical) narratologists is the link between ethics and empathy. A developed sense of empathy may allow one to understand the other and their ethical standpoints better, which can, in certain scenarios, create feelings of individual responsibility and call for ethical action (see Sainsbury, 2013, pp. 92-93). This is not just true for extra-textual empathy, as narrative empathy also has this potential effect on its readership (Hogan, 2011, p. 62). This may be why Patrick Colm Hogan states that empathy is "the origins and groundings of ethics" (2011, p. 62). Additionally, empathy makes the reader a participant to the events and the narrative, which makes it an excellent avenue for ethical analysis (Nussbaum, 1990, p. 46).

In talking about readers and engagement in this fashion, we are talking about consciousness. Considering the connection between ethics and empathy, Nikolajeva states that "[e]thical values are an essential part of any consciousness and thus motivate people's behaviour and relationships with other people, as well as with the physical and social environment. Understanding other people's ethical beliefs is therefore a vital constituent in theory of mind and empathy" (2018, p. 84). However, as Nikolajeva points out, when talking about children's literature we are talking about a group of readers who are both inexperienced readers and still cognitively developing. Nuance may thus be missing in the inexperienced reader's understanding of ethics, which is why a significant amount of story ethics takes place in action and dialogue. Additionally, it is specifically regarding ethics that the risk of identification is important, as when a reader identifies and engages too closely with a character (a higher risk for novice readers) it may become difficult for them to distance themselves enough not to adopt ethically problematic aspects of that character.

Using narratology, a narrative can be divided up into two parts: the story, or "what happens", and the discourse, which is how the story is presented (Chatman, 1978 , p. 19). The story/discourse distinction lends itself well to this analysis, as the aim is to investigate how ethics is constructed and communicated in a text as a whole; through both the overt philosophical debates and issues posed by the characters in the story, and through the manipulation of its presentation. On the discourse level, ethics is predominantly conveyed through various narrative devices such as direct and indirect speech and thought, free indirect discourse or FID, focalisation, 
narration, and other narrative strategies. On the story level, it is conveyed mainly by characterisation, actions and reactions. Analysing the ethics of children's literature in this way I heed Mills' warning about the possibly contradicting moral frameworks presented by a narrative, by addressing the way both elements impart their ethics. However, the narrative as it is presented to the reader does not come in two neatly separated parts, and its impact is equally blended. Therefore, this approach is more of a theoretical exercise in exploring how the ethics of the narrative is constructed on the story and discourse levels, and how these interact with one another.

I exemplify my approach through an analysis of Robert Westall's The Machine Gunners (1975). I do this by first laying the philosophical foundation for the approach, analysing how different normative ethical frameworks underline the whole of the narrative. Then, I discuss the way the story of The Machine Gunners constructs its complex morality. I then zoom out further, taking a step back to the discourse of the narrative. Through my analysis of this level of the narrative I dissect how the narrative ethics is made increasingly complex and ambiguous by the addition of covert morality and focalisation. I finish my analysis by turning to the ever important issue of endings, focusing on the moral implications of adult authority and punishment. By taking all these elements of the narrative into account, I propose a holistic approach to narrative ethics.

\section{Philosophical Ethical Frameworks}

Analysing a narrative within clear distinctions of story and discourse levels risks clearly delimitating what is in actuality a blurred line: narrative ethics is communicated through a combination of both levels, and occurs across the boundary between them. By studying the two levels both as separate and as narrative strategies which are in communication with each other, a holistic approach to narrative ethics is attempted. Analysing the narrative through the use of philosophical ethical frameworks can be an addition to this approach, as it forces the analyser to consider the narrative as a whole. Therefore, before I move on to my story/discourse analyses, I employ normative ethical studies, the aspect of ethical studies concerned with the principles, rules, and guidelines by which to live, to The Machine Gunners to create an ethics philosophical foundation for the rest of my approach.

Within normative ethics there are three main identifiable strands which focus either on consequence, motivation, or virtues as the sole indicator of correctness or incorrectness (Baron, Pettit, Slote, 1997). Thus the study of ethics can be divided up into consequentialism, deontology, and virtue ethics. For the pure consequentialist it is only the consequences of actions that make them ethically correct or not (Sinnott-Armstrong, 2015). Neither intention nor the act itself are a factor for this strand (Baron, Pettit, Slote, 1997, pp. 92-174). Deontological ethics, popularised by Kant, stands in stark opposition to this as it is mainly concerned with intentions. This is underlined by a sense of duty and obligation, or dignity. At its heart, deontology sees adherence to or deviation from a series of absolute rules as that which determines the morality of both action and character (Baron, Pettit, Slote, 1997, pp. 3-91). As summarised by professors of law Larry Alexander and Michael Moore, "deontology 
falls within the domain of moral theories that guide and assess our choices of what we ought to do (deontic theories), in contrast to those that guide and assess what kind of person we are and should be (aretaic [virtue] theories)" (Alexander, Moore, 2016). Virtue ethics is separate from both of these approaches, and has its focus not on action but on character instead. A virtue philosopher, such as Aristotle, considers what traits make one "good" and how one can best allow them to realise their particular "purpose" (Baron, Pettit, Slote, 1997, pp. 175-238). As emphasised by moral philosophers Rosalind Hursthouse and Glen Pettigrove, "virtues and vices will be foundational for virtue ethical theories and other normative notions will be grounded in them" (Hursthouse, Pettigrove, 2016).

These are clear and different approaches, and although a character may lean towards or imply a certain strand more than another, or even as the only correct one, in practice these strands often get mixed. According to ethics philosopher and scholar Robert Roberts this is because: "Unlike actions, traits of character are not datable occurrences in a person's history, but dispositions: temporally extended qualities that are exhibited presently in action, intention, desire, thought, and emotion" (2012, p. 1744). Instead of having solidified moral thoughts combined with "fixed possibilities" (Mahon, 2017, p. 108), most people's applied morality is vague and flexible. Consequently, the study of what is ethical in a psychological sense concerning human interaction tends to go beyond mere condemnation of an action or a thing as being either "good" or "bad"; instead it is the study of the philosophical virtues, of nuances and grey areas, of both intention and consequence (ibid.). Although the categories of consequentialism, deontology, and virtue ethics are useful tools to analyse the ethics of a character or action, merely labelling someone as one or the other misses the nuance that is part of all human motivation and action. This nuance can be analysed at length in literature, which unlike extra-textual life provides a complete overview of what is deemed relevant to the events and characters engaged with ethical problems.

Robert Westall's The Machine Gunners is set in WWII England and tells the tale of Chas and his friends, who steal a machine gun from a crashed German bomber and hide it in a fort they build specifically for it. There they encounter the injured German airman Rudi, who against all odds they befriend and nurse back to health. A false invasion alarm at the end puts the children's alliances to the test and ultimately sees them punished for breaking laws both unwritten and of the land. Throughout, the moral message appears to be one of an empathy-based ethics, of caring for each other and about the Other, and helping those in need. Courage and patriotism are framed as desirable and positive, as foregrounded by Chas' father's defence of his son's actions:“'I'll not say much for my lad,' said Mr McGill slowly, 'except he thought he was fighting the Germans' [...]. 'I'm not talking about his sense, missus. I'm talking about his guts' "(1975, pp. 197-198, emphasis in the original). However, these virtues need to be practiced in moderation. Mr McGill's decision to stick to his post of phone operator instead of helping his wife find their son in the middle of the "invasion" is judged by both his fellow wardens and his wife, the latter exclaiming" 'Your own bairn, and you wouldn't look for him. God forgive you, for I never shall' " (p. 175). Here Mr McGill's decision to fulfil his patriotic duty, normally a positively framed choice, is overshadowed by his lack of commitment to his 
family. This, as well as the children's foolishness with the aim of patriotic courage, has the air of a virtue ethics: be good, and do all good in moderation.

This virtue ethics is combined with an underlying consequentialism. The children commit many actions which are normally frowned upon as morally lacking, such as thieving, lying, and manipulation, yet they are hardly commented on at all. This is because they commit these acts mostly for the greater good: they steal food and supplies for the Fortress, lie about their activities because they believe (and are probably right to do so) that the adults would take away the machine gun and the children's chance to "do their bit" for the war effort if they found out, and manipulate others into helping them to create this chance to aid the British war defence against invaders. The adults mostly act within these same ethical frameworks: SergeantMajor Sandy Sanderson "wins" supplies for the Home Guard; Stan Liddell attempts to manipulate the children into telling him the truth; and Cemetery Jones Senior empties a tomb for his family to shelter in.

There is a strong sense of duty running throughout the narrative as well, betraying a deontological perspective enhanced by the war situation. Stan Lidell's (or in fact anyone's) engagement with the Home Guard, the children's desire to "do their bit", and Mr McGill's dedication to his switch board duties are all symptomatic of a sense of obligation to the nation, a need brought to the foreground by the threat of war. However, this deontological frame of mind is also constantly undermined. The Home Guard is a joke; comprised of men unfit for duty of any kind and criminally understocked, the sense of duty that drove these men to join the Guard ends up a mockery. The children "do their bit" by causing mayhem with a machine gun, ultimately causing the severe injury and potential death of their friend Rudi through utter confusion caused by a mistaken invasion warning. Their sense of duty thus ends up severely harming a close compatriot. Mr McGill's aforementioned staunch dedication to his job, even when his own child is missing, receives severe judgement from both his co-workers, who no longer look him in the eye, and his wife, who claims she cannot forgive him. A pure deontology therefore, although a strong factor of the war situation and a driving force of the plot, is ultimately criticised by the narrative.

These underlying philosophical frameworks are unlikely to be translated directly to the young reader, and do not need to be. Although an analysis such as the above may seem to suggest that a narrative blatantly states "deontology is bad, a blend of virtue ethics and consequentialism is good," that is both untrue and not the intention of such a reading. Rather, studying and verbalising these underlying and historical philosophical concepts reveals the presence and potential pervasiveness of certain moral attitudes, norms and values in society. For literature is a form of societal selfpreservation: desirable mores are written down to be taught to future generations in attempts to socialise them within these moral frameworks. Self-sacrifice, for instance, is argued to be a classic moral lesson of children's literature, taught both overtly and covertly from the inception of the field (Barker, 2014, pp. 102-103); though this position is not universally agreed upon (Nikolajeva, 2014, p. 185). Although this lesson is not spelled out to the reader of The Machine Gunners, and is arguably not the main moral point made in the text, the positive framing of personal sacrifice in the ending does communicate this message. The text's blend of virtue 
and consequentialist ethics combined with its emphasis on an empathy-based ethics in both the discourse and story tell a tale of children learning to care for people other than themselves, including even the enemy Other.

\section{Story Ethics in The Machine Gunners}

The Machine Gunners lends itself to a holistic ethical analysis through its focus on obedience, naughtiness, rebellion, and shifting alliances. It is a WWII story set in England, which in its early chapters appears to set up a stark binary between the English and the Germans-challenged later in the novel through the humanisation and focalisation of Rudi. This falls into line with other narratives such as Michael Morpurgo's Friend or Foe (1979), Jan Needle's A Game of Soldiers (1985) and Robert Westall's Blitzcat (1989). The Germans are Othered; they are not known, seen, or heard of by the characters nor the reader until the appearance of Rudi midway through the novel, and throughout the novel are framed by the adults as villainous. It is of note that all English adult characters, who hold authority over the child characters, both have and express intensely negative views of the Germans, which they do not hide from the children. As Gillian Lathey argues, the ideology of the time is represented both by the attitudes of the adults and the children's perspectives because "the essential messages of propaganda campaigns and public opinion reached children via the media or in their conversations with adults" (1999, p. 202). The children then are expected to pick up on this attitude, and generally do. When the children set up their fort in Nicky's garden, their (mostly) pretend play is that they are holding the fort against German enemies, whom they intend to and do gun down when a fighter plane flies over.

\section{Action, Dialogue, Ethics}

In the story level of any narrative, action and dialogue are of key importance to both characterisation and the ethical. To act is to act ethically, as there are no actions without ethical consequences nor any without moral consideration. These actions can be large or small. An example of a small action in The Machine Gunners, for instance, occurs when Rudi first stumbles across the children, both sides are terrified, and the children scramble to assess the situation:

\footnotetext{
'What are we going to do?' screamed Cem. 'He's a Nazi!'

'He's no sae like a proper Nazi,' said Clogger dubiously. And indeed the tattered wretch before them was not much like those black shiny-booted stormtroopers who goose-stepped nightly through their dreams.

'He ain't got no swastikas!'

'He's not a blond beast!'

'He looks hungry,' said Audrey. 'Can I give him a mug of tea?' (Westall, 1975, p. 124).
} 
After being given permission, Audrey performs the ostensibly small act of providing the Nazi stranger with a cup of tea. However, this act is deeply ethical; she reaches out to help a Nazi airman who needs it, and in doing so crosses the moral lines between them. In so doing, she crosses ingroup and outgroup divides. This action is based on empathy for the Other; Rudi, as both the enemy and an adult, is firmly placed in the children's outgroup. Yet Audrey's small action displays her empathic and moral abilities to see beyond such distinctions.

A large action occurs when the most vulnerable member of the group, Nicky, gets bombed out of his house, losing his home and his mother. Terrified of being put in an orphanage, he asks the other children to let him secretly live in the fort. After a meeting, they decide to shelter him and keep his secret together: "EEveryone swear ... on the gun.' So they brought the gun out of its wrapping, and laid Granda's Union Jack on it, and everyone put their hands on the gun and swore to look after Nicky" (Westall, 1975, p. 98). This action is larger than Audrey's tea handing because of its complexity, the debate that came before it, and because of its implications. The children know that they ought to bring Nicky to the adults, which would be following the mores and rules of their society. It is fair to presume that if the adults were to find out that the children hid Nicky, there would be ramifications of a larger scale than for Audrey's empathy for Rudi. Additionally, sheltering Nicky in their bomb shelter is not a permanent solution and would have to be addressed again as soon as circumstances change. They also know, however, that Nicky being placed in an orphanage would remove him from his home and only friends. The war also greatly damaged the children's faith in the adults' ability to protect and take care of them. Nicky begging his friends to shelter him and keep him hidden is a direct appeal for them to act empathically towards him. In this act the children do not cross the major empathic border between them and an Other like Audrey did for Rudi; however, their action does go against the adults' rules and power. Acting against particular ethical norms and values because of empathy characterises the children as caring, and a strong ingroup which is capable of compassion for outgroup members.

Like action, dialogue can reveal character motivation and morals: truthfulness of the dialogue, what is disclosed and what is not, and which characters are interacted with; all reveal the ethical framework in which the character operates. In this sense speech is an action, and carries similar ethical implications as action does. Chas, for instance, lies to all adults and feels no qualms about it. Lying is generally not seen as an ethically desirable trait, with a lot of emphasis placed on truthfulness as a virtue especially for children, and having a protagonist openly be a liar may make them morally ambiguous and complicated. However, as demonstrated at length by Kerry Mallan in Secrets, Lies and Children's Literature (2013), lying itself holds an ambiguous place in children's literature and culture alike, and "to dismiss or condone lying and deception as 'natural' or to condemn all lying as morally reprehensible simplifies and obscures other factors which account for why we often choose to lie or deceive rather than tell the truth" (p. 212). Additionally, as stated by Bettina Kümmerling-Meibauer and Jörg Meibauer, lies are only potentially morally ambiguous, and if a child does not learn how to lie this belies disordered development (2011, p. 164). The ability to lie is expected from neuro- and socially typical 
children, sometimes even necessary for survival, and can therefore not be seen as inherently evil.

Although the child characters, as well as Sandy Sanderson, often deceive the adult characters, which goes mostly unquestioned, the narrative does not present lying as a purely positive. This is most strongly exemplified by when Chas has to lie to his father, who is "the only one Chas could never have deceived" (Westall, 1975, p. 43). Chas asks his father if he can swap his trainset for his friend's telescope, which is much more valuable than the trainset. After hearing Chas and his friend got approval from his father, Mr McGill enthusiastically approves, and offers to make a tripod for it so it can stand up. However, Chas never wanted the tripod for the telescope, instead intending to use it for the machine gun. Additionally, Chas' friend's father was never involved in the made-up transaction between telescope and trainset. This lie makes Chas feel like "a rat. It was a much worse pain than parting with his beloved railway" (p. 110). Chas chooses to lie to his father in order to have the machine gun repaired, juggling his moral beliefs on the importance of the machine gun and "doing your bit" for the war, and his view and beliefs on his father as a formidable figure of authority.

As Mallan would phrase it, through lying Chas chooses "to become an active subject with the power to resist [adult] domination" (2013, p. 212), particularly his father's domination, which foregrounds Chas' moral dilemma. Admitting that he needs his father's help with the machine gun, rather than a camera tripod, would result in the loss of the machine gun and all of the children involved getting in trouble. Lying would mean that the machine gun gets repaired, and nobody gets in trouble. From the perspective of doing what you can to defend your country, this lie could be entirely justified. Chas's love for the machine gun, however, is not just a deontological focus on its importance in the war; it is the one piece that makes his war souvenir collection the best in the land. Therefore, Chas's defence of and attachment to the machine gun is not morally "pure", and his lie is equally ambiguous. Highlighting Chas's intense negative emotions resulting directly from his lie against his father potentially makes it more palatable for the reader, however; especially the comparison to the feeling of loss of a beloved toy serves to strengthen extradiegetic empathic engagement.

\section{Discourse Ethics in The Machine Gunners}

There are many elements of the discourse of a narrative which may communicate ethics, such as grammar, focalisation, tense, and sequential ordering. The order of a narrative, placing certain plot elements or dialogues in particular places, serves to emphasise or de-emphasise a point or approach the narrator makes. As such, sequencing a narrative works in a similar fashion with extradiegetic empathy as with the creation of narrative ethics: through foregrounding of certain events, actions, and characters, the reader is manipulated to side with certain characters over others (Bal, 1997, p. 82). Ethically this means that the reader is presented a particular view of events and their contexts, and therefore more likely to adopt the moral framework which suits that presentation. In The Machine Gunners, the sequencing 
is most effective in that it forces the adult perspective into the narrative. In these episodes the adults portrayed are shown not to be brave and capable; rather, they are incompetent, insecure, and constantly outwitted by each other and the children. By cutting to the adults only in these moments, the image of the adults as unreliable is enhanced and the children's decision to move behind their backs is justified. In this way, the narrative strategy of sequencing adds to the moral framework contained in and expressed by the novel.

\section{Communicating Ideologies}

As is the case with narrative ethics, ideology is an aspect of every story in both an overt and covert fashion (Hollindale, 2011, p. 9). Peter Hollindale argues that ideology is present in children's literature in three ways: in the explicit(ly stated) beliefs of the author (p. 36), in the author's unexamined assumptions (p. 39), and in the "shared understanding" of the world, a matter of zeitgeist. Hollindale names this "organic ideology" (p. 42), organic because they are underlying for the functioning of the world and are both unquestioned by the narrator and the characters, and therefore assumed to be shared beliefs between the narrative and the reader. On the discourse level this implicit ideology is the easiest to pin down in the analysis of setting, characterisation, and narrative gaps. The way in which the implied reader is supposed to or does fill in the narrative gaps suggests an internalisation of implicit ideologies (Stephens, 1992, p. 10). The presence of such an ideology is inevitable, as every narrative's construction must have gaps, and these gaps must be filled by the implied reader. Filling in these gaps takes cognitive activity, which allows space and time for growth.

The ethics propagated by The Machine Gunners is one based on empathy and wanting to do right by others, even the enemy Other. However, the narrative does not extend this empathy to all characters and considers some as lesser, and therefore not deserving of empathy or moral action. Covert communication of ideology, the organic ideology, is the strongest and potentially most dangerous as the implied reader, especially an inexperienced reader, is more susceptible to that than to overt means. In The Machine Gunners the most covert and unaddressed ideologies are classism and an undercurrent of racism. The classism is the most apparent when Chas sees a working-class family in the beginning of the novel when he is hunting for war souvenirs. Chas immediately dehumanises them:

The family were scurrying around like ants from a broken nest, making heaps of belongings they had salvaged, and then breaking up the heaps to make new heaps. Chas watched them as if they were ants, without sympathy, because they were a slummy kind of family; a great fat woman in carpet slippers and a horde of boys of assorted sizes; hair like lavatory brushes, coarse maroon jerseys that wouldn't fasten at the neck and boots with steel heelplates (Westall, 1975, pp. 4-5; emphasis mine).

The comparison of the family to ants is a means to picture them explicitly as an Other, or outgroup, as grotesquely different to the ingroup. As cognitive 
psychological research has demonstrated, ingroup membership greatly limits the ability to empathise with and act ethically towards outgroup members (Sparks, Schinkel, Moore, 2017, p. 246), which Chas demonstrates by his disgust for the working-class family. Here the family is dehumanised first in FID, which blends the authority of the (implied adult) narrator and the opinions of the child character. The effect of this is that a character's opinion may come across as true, and as this is the first description the reader gets of this family it potentially has a lasting impression of them as Other and lesser. The following sentence clarifies that it is Chas who passes the classist judgement on them.

The narrator's interjection of "without sympathy" is interesting as it both criticises Chas for dehumanising the family and at the same time implies that sympathy is an appropriate emotion to experience while gazing at a working class family. Additionally, the next clause passes further judgement on the family once again in FID. Therefore, although the narrator appears to find and present Chas' views of the family as disagreeable, the narrative perpetuates these views itself by presenting Chas' classism through the medium of the narrator's authority. Classism forms a part of the text's underlying ideology, which although it is foregrounded by the narrative remains unresolved. Therefore, as Hollindale would say, the questionable values of classism which "seemed to be on trial" (2011, p. 48) are reaffirmed by the narrative. By foregrounding but not resolving the issue of classism, the narrative communicates not only that such values and judgements exist, but potentially that this is not a negative viewpoint to have.

\section{Focaliser Ethics}

The power balance between adults and children informs the ethical impact of a narrative on an inexperienced reader in the discourse, as the age gap between narrator and focaliser influences the way readers are presented with the ethical discourse (Fjällström and Kokkola, 2014). As Mieke Bal states: when the narrator is not a child, but the focaliser is, this highlights the difference between the two roles (1997, p. 148). Additionally, the focalised character "will have an advantage over the other characters. The reader watches with the character's eyes and will, in principle, be inclined to accept the vision presented by that character" (Bal, 1997, p. 147). Thus, as the implied reader is presumed to empathise the most with the focalised character, they are also likely to adopt that character's moral views.

The discourse of The Machine Gunners is particularly interesting in regards to this child-adult ethical power relationship and its empathic basis. For most of the narrative, the focaliser is either the protagonist Chas or another of the children. However, there are also many, albeit brief, instances mentioned above where the chief focaliser of a chapter is an adult. The first of these is in Chapter Four which is from the perspective of English teacher Stan Liddell. Before this chapter, Liddell is introduced as "Mr Liddell, the English master", "The English master", and "Captain Liddell of the Garmouth Home Guard" (p. 13). Yet chapter four refers to him by his first name exclusively, and through his subordinate relationship with the Headmaster portrays him as similar to the children in that regard. 
Stan Liddell gets several chapters and sub chapters dedicated to his attempt to recover the missing machine gun, suspected to be taken and hidden by Chas, and to prepare the Home Guard for invasion. In all but the last chapter, Stan's focalised chapters portray him as "awkward" (p. 31) and uncomfortable with authority. This is a narrative strategy aimed at achieving multiple things: creating the potential for extradiegetic empathy with the (adult) man who is trying to apprehend Chas by infantilising him to an extent, and the linked goal of opening the ethical horizons of the narrative so it is not limited to Chas' ethical framework. It also forms the opportunity for an ethical dialogue within the narrative; and generates narrative tension by adding a cat-and-mouse element to the story.

During the adult focalised parts of the narrative the adults only interact with other adults, and the child characters' actions and minds are hidden from the reader. By hiding actions and emotions, both of which are all ethically charged, the narrative foregrounds a different moral framework at different points of the narrative. The main framework shown and developed throughout most of the story is that of Chas, and in this way it is safe to say that the narrative favours Chas' moral development over the other characters'. The arrival of Rudi, again, is an intended complication to this setup. Rudi is introduced to the narrative midway through the novel, at which point focalisation is split almost evenly between Rudi and Chas. The language Rudi uses mirrors the language German characters would have used in English boy's magazines and comics of the time (Lathey, 1999, p. 201), with its unrealistic grammatical errors and misspelled "evil German" phrases (like Hande hoch! Instead of Hände hoch, or Dumkopf instead of Dummkopf). Using this language provides a more modern reader insight into and possibly even promoting engagement with the ideology of the time, which Othered Germans and would have reduced Rudi to an unrepentant, purely evil Nazi. However, access to Rudi's emotions, thoughts and fears for extended periods of time demystifies him and moves against simplistic Othering (idem). Providing this much focalised insight into Rudi's character is a narrative strategy with the aim of enhancing the chances of empathic engagement with a German character who would previously be considered the enemy, and therefore evil, and through that broadening the moral frameworks and implications within which the narrative operates.

\section{Rounding Things Off}

The way through which a story is ended has a particularly strong impact on the ethical ramifications of the narrative. Closing a story with a happy ending no matter the horrors that are told within it can be considered damaging to the moral message of the text, as it could potentially seriously weaken or even negate the apparent ideological stance of a narrative. An example for this, for instance, is Jane Yolen's Shoah novel The Devil's Arithmetic (1990). In The Devil's Arithmetic the story climaxes when the protagonist decides to sacrifice herself to be killed in a gas chamber so another may live. This strong ethical choice is negated when there are no consequences for that action: the protagonist "wakes up" in her family's home, and instead of causing harm her sacrifice led her to become closer 
to her family and faith. Thus the ethical charge of sacrifice is lost. As Peter Hollindale argues, the issue of happy endings is that they may "amount to a "contract of reaffirmation' of questionable values which have earlier seemed to be on trial" (2011, p. 48). Additionally, closing a story without wrapping up thematic or ideological issues is in itself an ideological issue (Stephens, 1992, p. 42). As such, endings have a strong impact on the ethical aspect of the narrative and are ethical issues in themselves. This means that the final element of the narrative; the ending, whether happy, ambiguous or sad, is an ethically charged narrative strategy which may serve to communicate a particular moral message to the cognitively developing reader.

The ending of The Machine Gunners punishes everybody. The children are apprehended, as they have committed several crimes including accidentally shooting at allied forces. They do not try to fight against the adult authorities and accept whatever punishment comes their way. After saying their goodbyes "they parted, never to be all together again. They walked across to their parents. Their arms were grabbed roughly, and they were led away" (p. 198). Punishment itself is an ethically charged word, as it implies guilt and jurisprudence. In that regard it deals with justice, but also with the emotional-ethical element of decision making and language: to call something punishment is to assign blame, and to accept punishment appears to imply acceptance of that blame. However, in situations like this where there is a significant power imbalance between the punisher and the one accepting the doled out punishment, there is also the possibility that the party found guilty accepts because they cannot defend their position against the other. This complicates the ethical nature of the decision to accept punishment through resignation, but in this case it is particularly interesting for the study of narrative endings.

Throughout the narrative, the children (particularly Chas) have rebelled against adult authority and morality. They steal, deceive, lie, manipulate, and mock the adults in their society, and do not accept their normative morality. This is the clearest in the ending, where all adults through cowardice fail in their response to the perceived invasion, and the children who have families actively judge, reject and run away from their parents. To borrow phrasing from Beauvais, the adults are here shown as "lacking". However, at the end the children are not only returned to adult authority, but also appear to accept the adults' imposed morality in the form of punishment without resistance. This potentially complicates the moral message about righteous rebellion against aetonormativity. However, the children are not left as powerless subjects to their parents; even in the face of punishment they remain rebelliously "mighty". The adults through their punishments of the children betray being stuck in their moral frameworks; although Mr McGill, Sandy Sanderson, Stan Liddell, and Cemetery Jones Senior all take pride in the children's inventiveness and courage, they cannot remove themselves from their old ideas of properness for children, and refuse to allow the children freedom to act as they please. They are, as Beauvais phrases it, "trapped in the centre of a glutinous web of commitments, stuck into a situation, characterised by having-been-ness" (2015, p. 56). The novel ends, however, on a defiant utterance by the most submissive child, Nicky: 
'C'mon, son,' said the police sergeant to Nicky. 'You're going to tell me all about this. You're a cut above the rest of this riff-raff, you know. Your father was a ship's captain. God knows what he'd have said.'

Nicky took a deep breath.

'Get stuffed,' he said. (Westall, 1975, p. 199).

Nicky's rebellion against the adult authority allows the narrative to end on a tentatively hopeful note: although the children are made subject to the adult authority, the way they react to this is left open to the future beyond the book, the readers' imagination. Ending the narrative in this way demonstrates the impossibility of fully predicting how the child will respond to the moral lessons to which they are subjected, and how they will act; it shows "the indeterminacy" that inherently goes with adult-child didactic engagement, betraying the child's might in the face of adult authority (Beauvais, 2015, p. 57). Additionally, the ending is dominated by a resentment at the adults' responsibility for both the confusing nature of the ending scene, and the war itself. The anti-adult sentiment is reaffirmed when all of the adults entering the fortress to punish the children are reduced to enemies (Lathey, 1999, p. 199).

\section{The Importance of a Holistic Ethical Analysis}

Novels like The Machine Gunners allow for an analysis on both the structural and the philosophical level because they demonstrate how a text can support some of its moral claims and contradict others at the same time. Yet, as all narratives are created through specific choices and strategies, so they also each have particular ethical messages and implications. Analysing a narrative in this manner demonstrates the moral contents of a narrative as they are presented to the reader, the different ways through which this is done, particular ethical implications of certain narrative strategies, and the contradictive nature of narrative ethics. In this article I have also made clear the importance of such an approach to children's literature specifically and made the point that for young and inexperienced readers who are still developing cognitively, and need to learn their society's moral codes, the ethical implications of specific narrative structures are crucial. Novice readers are distinctly vulnerable to the discourse level of narrative ethics as it is covert and implied, and as they may not be aware of what the narrative is communicating to them, they may not resist. Unquestioning acceptance of moral frameworks and modes of thinking is potentially dangerous, especially when considering that the decision to implement certain narrative strategies can be subconscious.

An added layer of reader vulnerability arises in the form of story ethics, which is particularly impactful because of its close links to narrative empathic engagement. When the reader is empathically engaged with the narrative they are emotionally engaged, through which, because of the close links between ethics and the emotions, the reader is also ethically engaged. This is where the identification fallacy is particularly risky: when the reader is too closely engaged with a character, it may become difficult for them to distance themselves enough not to adopt ethically 
problematic aspects of that character. However, as the reader develops cognitively and gains literacy skills, the risk of them being unable to resist focalisation and immersive identification may reduce. As Eva Fjällström and Lydia Kokkola found in their empirical study of Swedish sixteen-year olds reading Irish fiction in its original Hiberno-English, teenagers do demonstrate the ability to resist focalisation (2014). Although this study only included thirty-three students, it also important to remember that these readers were confronted with a text which was both linguistically and culturally foreign to them, circumstances which greatly enhance the cognitive challenge posed to the readers. Not all students involved in the research were able to resist focalisation, possibly a result of differences in verbal literacy between the participants. As literacy is a skill which takes time and training to develop, focalisation and the moral frameworks presented through it are harder to resist for less experienced readers. For these readers the narrative technique of defamiliarization may be fruitful as it stimulates empathy whilst discouraging immersive identification, and through that discourages adopting the value system tied to the character (Nikolajeva, 2018, p. 85).

In this article I explored the links between and implications of particular narrative strategies in an example of children's war literature and its potential cognitive impact on an inexperienced and developing readership. Its link to empathic engagement analysis is clear; emotions are ethical, and empathic engagement with characters opens up a sharing of both emotional and ethical information and experience. Furthermore, as children's literature enhances the importance of such engagement with the text, so the setting of war exacerbates both the emotions and the ethical ramifications and consequences of actions. My analysis of The Machine Gunners exemplifies the benefits of my holistic approach to narrative ethics in children's war literature and lays bare the combined impact of story and discourse in the construction of a narrative's moral contents and message. Even literature written for young readers comprises complex narrative strategies and corresponding ethical implications, which, based on its intended audience, suggests it is has critical social and political importance.

Open Access This article is licensed under a Creative Commons Attribution 4.0 International License, which permits use, sharing, adaptation, distribution and reproduction in any medium or format, as long as you give appropriate credit to the original author(s) and the source, provide a link to the Creative Commons licence, and indicate if changes were made. The images or other third party material in this article are included in the article's Creative Commons licence, unless indicated otherwise in a credit line to the material. If material is not included in the article's Creative Commons licence and your intended use is not permitted by statutory regulation or exceeds the permitted use, you will need to obtain permission directly from the copyright holder. To view a copy of this licence, visit http://creativecommons.org/licen ses/by/4.0/. 


\section{Works Cited}

\section{Primary sources}

Haldeman, J. (2010). The Forever War. 1974. London: Gollancz.

Morpurgo, M. (1979). Friend or Foe. London: Egmont.

Westall, R. (1975). The Machine Gunners. London: Macmillan.

Westall, R. (1989). Blitzcat. London: Macmillan.

Yolen, J. (1990). The Devil's Arithmetic. New York: Puffin Books.

\section{Secondary sources}

Alexander, L., and Moore, M. (2016). "Deontological Ethics" (2007). Stanford Encyclopedia of Philosophy. https://plato.stanford.edu/entries/ethics-deontological/.

Bal, M. (1997). Narratology: Introduction to the Theory of Narrative (2nd ed.). Toronto: University of Toronto Press.

Barker, J.L. (2014). Virtuous transgressors, not moral saints: Protagonists in contemporary children's literature. In C. Mills (Ed.), Ethics and Children's Literature (pp. 101-124). Burlington: Ashgate.

Baron, M.W., Pettit, P., and Slote, M. (1997). Three Methods of Ethics. Oxford: Blackwell.

Beauvais, C. (2015). The Mighty Child: Time and Power in Children's Literature. London: John Benjamins.

Booth, W.C. (1992). The Rhetoric of Fiction. 1988. Berkeley, CA: University of California Press.

Chatman, S. (1978). Story and Discourse: Narrative Structure in Fiction and Film. Ithaca, NY: Cornell University Press.

Fjällström, E., and L. Kokkola (2014). Resisting focalisation, gaining empathy: Swedish teenagers read Irish fiction. Children's Literature in Education, 46(4), 1-16.

Hogan, P.C. (2011). What Literature Teaches Us about Emotion. Cambridge: Cambridge University Press.

Hollindale, P. (2011). The Hidden Teacher: Ideology and Children's Reading. Stroud: Thimble Press.

Hursthouse, R., and Pettigrove, G. (2016). Virtue ethics. (2003). Stanford Encyclopedia of Philosophy. https://plato.stanford.edu/entries/ethics-virtue/.

Keen, S. (2007). Empathy and the Novel. Oxford: Oxford University Press.

Kümmerling-Meibauer, B., and Meibauer, J. (2011). Lügenerwerb und Geschichten vom Lügen. Zeitschrift für Literaturwissenschaft und Linguistik, 41(162), 114-134.

Lathey, G. (1999). The Impossible Legacy: Identity and Purpose in Autobiographical Children's Literature Set in the Third Reich and the Second World War. Berlin: Peter Lang.

Mahon, Á. (2017). Moral education and literature: On Cora Diamond and Eimear McBride. Journal of Philosophy of Education, 51(1), 102-113. https://doi.org/10.1111/1467-9752.12183.

Mallan, K. (2013). Secrets, Lies and Children's Fiction. New York: Palgrave.

Mills, C. (2014). Introduction. In C. Mills (Ed.), Ethics and Children's Literature (pp. 1-13). Burlington: Ashgate.

Nikolajeva, M. (2014). Reading for Learning: Cognitive Approaches to Children's Literature. Amsterdam: Benjamin.

Nikolajeva, M. (2018). Emotions and ethics: Implications for children's literature. In K. Moruzi, M.J. Smith, and E. Bullen (Eds.), Affect, Emotion, and Children's Literature: Representation and Socialisation in Texts for Children and Young Adults (pp. 81-95). New York: Routledge.

Nussbaum, M. (1990). Love's knowledge: Essays on Philosophy and Literature. Oxford: Oxford University Press.

Nussbaum, M. (2001). Upheavals of Thought: The Intelligence of Emotions. Cambridge: Cambridge University Press.

Roberts, R. (2012). Narrative ethics. Philosophy Compass, 12(3), 174-182. https://doi.org/10.111 1/j.1747-9991.2011.00472.x.

Sainsbury, L. (2013). Ethics in British Children's Literature: Unexamined Life. London: Bloomsbury. 
Sinnott-Armstrong, W. (2015). Consequentialism. (2003). Stanford Encyclopedia of Philosophy. https:// plato.stanford.edu/entries/consequentialism/.

Sparks, E., Schinkel, M.G., and Moore, C. (2017). Affiliation affects generosity in young children: The roles of minimal group membership and shared interests. Journal of Experimental Child Psychology, 159, 242-262.

Stephens, J. (1992). Language and Ideology in Children's Fiction. Harlow: Longman.

Vermeule, B. (2010). Why Do We Care About Literary Characters?? Baltimore, MD, Johns Hopkins University Press.

Publisher's Note Springer Nature remains neutral with regard to jurisdictional claims in published maps and institutional affiliations. 